ISSN No. 0974-035X

An indexed refereed \& peer-reviewed journal of higher education

Towards Excellence

UGC-HUMAN RESOURCE DEVELOPMENT CENTRE

Gujarat University, Ahmedabad-380009, Gujarat, India

\title{
EXPERIENTIAL LEARNING METHODOLOGIES AND TECHNIQUES: ASSESSING THEIR POTENTIAL FOR EDUCATION FOR SUSTAINABLE DEVELOPMENT [ESD]
}

\author{
Paramjit Kaur \\ Prof. Saroj Sharma
}

\begin{abstract}
Rationale:

The implementation of Education for Sustainable Development (ESD) in the education sectors came as a call from the UN General Assembly that declared the years 2005 2014 as being Decade for ESD (DESD). Agenda 2030 is being pursued to meet the unfinished targets. The purpose of this study is to bring out the potential of Educational Practices [EPs] for ESD in schools of Delhi in order to make a contribution to the implementation of ESD in schools.
\end{abstract}

\section{Objectives of the Study:}

- To identify the EPs undertaken in schools to implement Education for Sustainable Development [ESD].

- To examine the role of identified EPs to develop ESD competencies.

\section{Methodology of the Study:}

The study was qualitative and exploratory in nature. Framework for the UNDESD International Implementation Scheme was used to delimit a themes or perspectives of ESD for the study. 
Towards Excellence: An Indexed, Refereed \& Peer Reviewed Journal of Higher Education / Ms.

Paramjit Kaur \& Prof. Saroj Sharma/ Page 102-112

Educational Practices [EPs] based on these delimited themes that are carried out in these 15 schools were then identified. The data from the interview was triangulated with observations.

No attempt has been made in this study to compare between the sample schools for the implementation of ESD; as this was not the purpose of the study. Also, focus of the study has been kept on the school-wide programme; keeping in view that an isolated EP cannot achieve desirable outcomes.

\section{Findings:}

Educational Practices included a systematic array of school activities, related policies, and approaches to achieve learning in ESD. Within these practices, there are different levels of complexity. These Educational practices had a common element- these EPs engaged the learners actively. Competency-building is promoted as learners dwell in these educational problems that simulate real-life experiences.

There is a tremendous amount of work happening on the ground but it is disconnected and not aligned to learning goals. In this regard, the competency based education emphasised in NEP should be carefully dwelled upon while giving form and structure to the EPs conducted for implementation of ESD.

Keywords: Education for Sustainable Development, Competency Based Education, Experiential Learning, Educational Practices

\section{Introduction:}

Historically speaking, Government of India has been a close partner of UNESCO policies in Education on all three focus areas - access, quality, and content. India has cooperated UNESCO in its efforts towards the Education for All (EFA) goals including the Post-2015 
global education scenario, particularly the Sustainable Development Goals (SDG). India's commitment to Goal 4 of SDGs is therefore implicit. While there is extensive body of research available for ESD at higher education level; very little literature is available for stage where it is most pertinently needed- in the adolescent and pre-adolescent period. Research establishes that effective pedagogical practices that involve experiential learning, problem solving, inquiry-based learning and other such progressive approaches can only help achieve targets of Goal 4 of 17 SDGs where inculcation of skills and values is under consideration.

This research was aimed at exploring the educational practices for ESD in context of urban school education in India in general and Delhi in particular. It explores pedagogy of ESD concepts that are created and implemented by teachers. Students' active participation in ESD, as well as their ESD-related competencies, is also empirically studied.

Agenda 21 (UNESCO) and Global awareness from DESD has established beyond doubt that ESD competencies require infused and integrated approach for acquiring knowledge and awareness to developing sensitivity and feeling concerned to developing environment [both natural and social] friendly habits and acquire competency to alleviate the problems associated with it from an early age.

Conventional teaching styles tend to put learners in a passive mode. Perceiving students as only recipients of knowledge; procrastinates their creativity, independent higher order thinking and innovation (NEP 2020). It also jeopardizes the competency- building in young learners.

It further recommends pedagogical approaches that have a strong interdisciplinary, multidisciplinary or trans-disciplinary element, reflecting the closely intertwined nature of constituent domains in sustainable development. Situated and problem-based learning have been proven to be best suited, to encourage students to inculcate their own values and appreciate 
Towards Excellence: An Indexed, Refereed \& Peer Reviewed Journal of Higher Education / Ms.

Paramjit Kaur \& Prof. Saroj Sharma/ Page 102-112

others'. A democratic learning set-up that has ample room for collaboration and group innovations; speeds up skill- learning, positive change in the attitude towards social and natural environment and inculcate values for harmony and peace. Countless such opportunities exist inside and beyond the 'classroom'. These allow and encourage students to be exposed to multiple perspectives and enable creative responses to emerge.

\section{ESD Competencies}

The ESD Toolkit 2.0 highlights that ESD develops skills of critical refection, leadership, meaningful communication as well as creates positive attitude for preservation of environment and culture. It promotes values of peaceful co-existence and mutual tolerance. It is this idea of competencies that can distinguish between "education about sustainable development" ( a theory lesson to "know') and "education for sustainable development" (education as a tool to build competencies for sustainable development).

Competency- building is also seen to be direct outcome of pragmatic learning opportunities seem to be a suitable way for students to build competencies related to sustainability. These pragmatic learning opportunities work in tandem with each other to facilitate shaping ESD competencies. These simulated real-lifelike situations provide a scope for problem based learning. These are complementary and supplementary to each other and may not produce desirable learning

outcome when carried out in isolation. According to UNESCO: there are five components of ESD competencies: Knowledge, Skills, Perspectives, Behaviour and Values. ESD competencies are the educational outcomes that can enable a student (future citizen) to think critically, adopt conventional solutions and be future ready for solving unprecedented problems that may arise in future. 
Towards Excellence: An Indexed, Refereed \& Peer Reviewed Journal of Higher Education / Ms. Paramjit Kaur \& Prof. Saroj Sharma/ Page 102-112

\section{Objectives:}

- To identify the Educational Practices [EPs] undertaken in schools to implement Education for Sustainable Development [ESD].

- To examine the role of identified EPs to develop ESD competencies.

\section{Methodology:}

The research was aimed at the process, meaning and understanding gained through interacting with the stakeholders. The use of qualitative approach in this study empowered the researcher to hear their voices, feelings and actions to understand the ground realities about the implementation of ESD in the school curriculum, and to identify practices schools have taken to ensure that ESD is put to practice. The study is delimited to 11 themes or perspectives of ESD selected from 3 pillars of Sustainable Development (SD as specified in the UNESCO policy documents. The selection is based on local relevance of themes as emphasised through school programmes of TERI, CEE, CBSE and UNDESD International Implementation Scheme.

\section{Table 1: Delimited themes}

\section{Themes from Social pillar of SD:}

\begin{tabular}{|l|l|}
\hline Ethics and Philosophy & 1 a. Citizenship and Democracy \\
\hline Human Rights & 1 b. Gender Sensitization \\
\hline Personal Health and Safety & 1 c. Reproductive and Sexual Health \\
\hline & 1 d. Managing Stress \\
\hline & 1 e.Cyber Security \\
\hline 2. Themes from Environmental pillar of SD: & \\
\hline
\end{tabular}


Towards Excellence: An Indexed, Refereed \& Peer Reviewed Journal of Higher Education / Ms.

Paramjit Kaur \& Prof. Saroj Sharma/ Page 102-112

\begin{tabular}{|l|l|}
\hline Ecological Principles/Ecosystem Approach & 2a. Natural resources \\
\hline Waste Management & 2b. Swachh Bharat \\
\hline Environmental Health & 2c. pollution/ smog in Delhi \\
\hline 3. Themes from Economic pillar of SD: & \\
\hline Production and/or Consumption Patterns & 3a. Make in India \\
\hline & 3b. Consumer rights and awareness \\
\hline & 3c. Financial literacy \\
\hline
\end{tabular}

To study educational practices with respect to their potential for ESD; it was imperative that schools with exemplary practices are chosen as samples. All the schools selected are senior secondary schools in Delhi region affiliated to CBSE and recognised by Directorate of Education, Delhi. Educational Practices [EPs] based on these delimited themes that are carried out in these 15 schools were then identified. Teachers from diverse subject backgrounds were chosen from each school, because the school system offers many educational practices and school- wide approach is essential to understand the holistic school programme. In this study, semi-structured interviews were important as these gave the researchers an opportunity to obtain the participant's knowledge, reasoning, motivation, feelings and experiences of the phenomenon under study. A checklist was prepared to identify the exemplary practices [that bear potential for ESD]. Each identified practice was then observed for detailed description. Observation helped to discover direct, first-hand experience information about real time execution of EPs. Observation provided in-depth information about the EP, its rationale and epistemological basis and 
Towards Excellence: An Indexed, Refereed \& Peer Reviewed Journal of Higher Education / Ms. Paramjit Kaur \& Prof. Saroj Sharma/ Page 102-112

principles of implementation. Content analysis of video records, circulars handouts, presentations and annual dossiers on these activities were also done. The data from the interview was triangulated with observations. The potential of these identified practices [mapped to the 11 themes] was found by a rubric. Eight essential elements were analyzed using descriptive indicators in the form of rubrics to find the Potential of the Identified Educational Practices for ESD. These were chosen on the criteria proposed by UNESCO policy documents. The 8 elements are: Relevance, Scope, Accuracy, Coherence, Depth, Authenticity, School- Wide Approach, Updating and Feedback.

No attempt has been made in this study to compare between the sample schools for the implementation of ESD; as this was not the purpose of the study. Also, focus of the study has been kept on the school-wide programme; keeping in view that an isolated EP cannot achieve desirable outcomes.

\section{$\underline{\text { Findings }}$}

A total of 22 EPs in each school were studied with respect to their potential to implement ESD as per the UNESCO guidelines. A comprehensive account of all EPs has been provided in Table 2 and Figure1 given below.

\begin{tabular}{|l|l|l|l|l|l|}
\hline Rubric score & Good & V. Good & Excellent & Exceptional/ Exemplary & Total \\
\hline Number of & 14 & 31 & 105 & 180 & 330 \\
practices & & & & & \\
\hline
\end{tabular}

Table 2: The potential of the EPs for ESD 


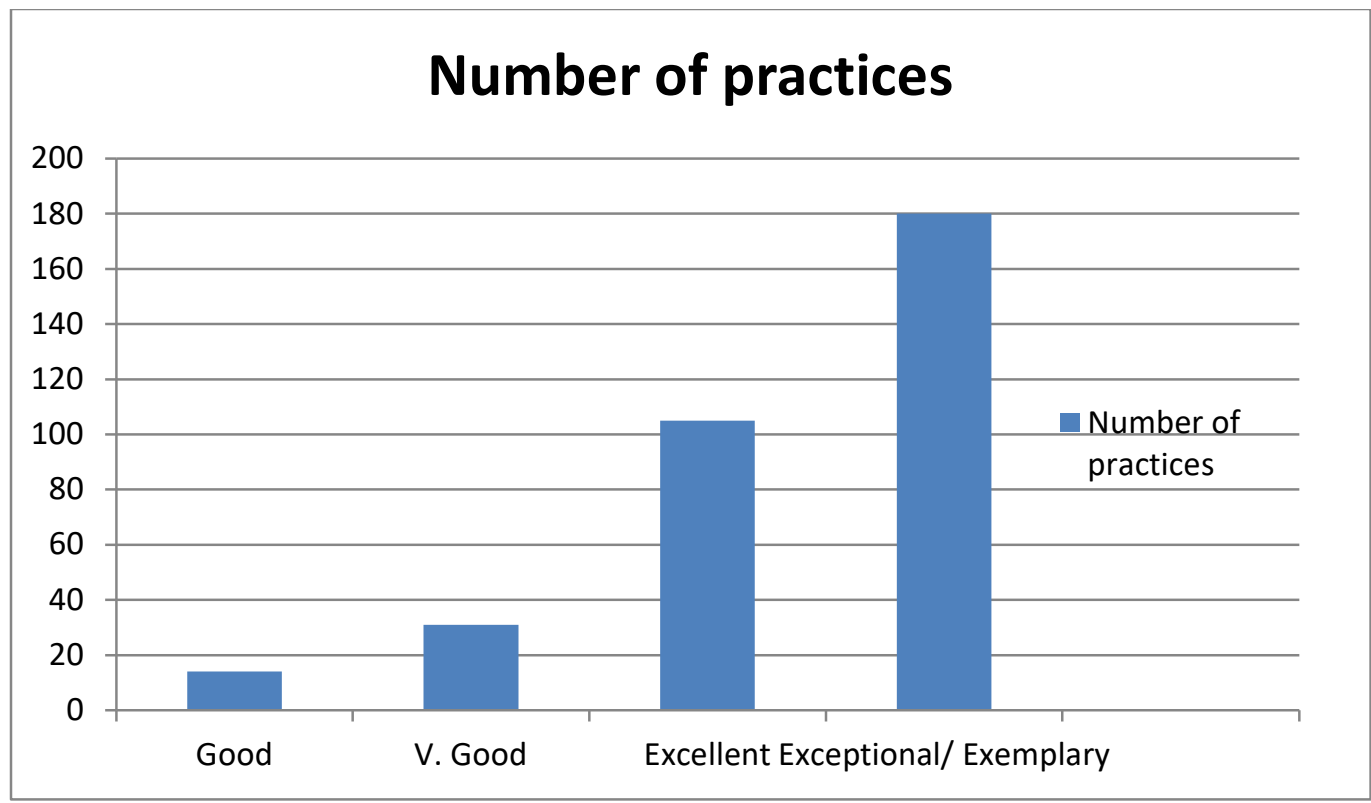

\section{Figure 1: The Potential of the EPs for ESD}

Educational Practices included a systematic array of school activities, related policies, and approaches to achieve learning in ESD. Within these there is rich diversity at the levels of scope, aim, styles and modes of implementation. While some EPs are basic policy decisions e.g., inclusion policy; others could be modular EPs e.g., instituting a student council. Still others could be a bundle of related EPs such as Eco-club initiatives. These Educational practices had a common element- these EPs engaged the learners actively. Competency-building is promoted as learners dwell in these educational problems that simulate real-life experiences.

Practices that have been just initiated cannot be left until they prove themselves in a real environment or a controlled experiment. These would need to be continuously updated, substantiated with new set of feedback and analysed. EPs with a potential for ESD can be adapted and implemented by other schools of similar setting. Not only this, an EP that reaches an 'exceptional' or 'exemplary' status would most likely begin from a potentially 'good' level initially. A school-wide integrative approach with embedded ESD is not an option but the only possible means to implement ESD. 
Towards Excellence: An Indexed, Refereed \& Peer Reviewed Journal of Higher Education / Ms.

Paramjit Kaur \& Prof. Saroj Sharma/ Page 102-112

The following illustration typically differentiates these levels: Student Council was an EP researched in the category- 1a. Citizenship and Democracy included under ESD Theme: Ethics and philosophy. This EP involved sequential processes of campaigning, election, selection and nomination in the simulated election activity mostly run through first month of the academic session. The EP is conducted as a part of basic school programme. The objective of the EP is to help students recognise concepts and practices related to Elections, self- governance and leadership. A students' governance body is constituted where they represent themselves and address their issues. This is variously called as the Students' Council, Prefectorial board, Students' Cabinet etc. This can be an elected or a nominated body or a combination of both. If based on elections; students vote for their representatives. If nominated, teachers nominate, else students vote for the nominated candidates. Contestants prepare a manifesto and campaign. After being elected, representatives assume office to impact duties such as organizing and managing events, maintaining discipline in campus etc. the elected representatives may also be provided leadership training. The expected learning outcomes are that the students will be able to frame rules for themselves and abide by them. Students will understand principles of democracy and governance. In the schools where the elected council is also a part of the students' discipline committee; it helps to instil competency for recognising natural justice. Students will be able to display problem identification and solving skills.

Moreover each school has to experiment with their own set and concretize their own customised set. ESD is to be identified more as an 'approach' than as curriculum itself. ESD cannot be limited to the academic curriculum; it is inherent in its character to be achieved through the learning opportunities present co-curricular and informal school settings in the school such as bulletin board activity in the school corridors, assemblies in the school field, community service 
Towards Excellence: An Indexed, Refereed \& Peer Reviewed Journal of Higher Education / Ms. Paramjit Kaur \& Prof. Saroj Sharma/ Page 102-112

program, recycling initiatives, road safety awareness session, peer moderator workshops etc. the educator should be trained to recognize potential learning grounds and create them into an effective learning approach and space.

\section{$\underline{\text { Educational Implications: }}$}

There is a tremendous amount of work happening on the ground but it is disconnected and not aligned to learning goals. In this regard, the competency based education emphasised in NEP should be carefully dwelled upon while giving form and structure to the EPs conducted for implementation of ESD. Learning approaches conventionally known to be 'co-curricular' or 'coscholastic' are the ones that have the biggest potential for competency based learning. Advocated in the NEP 2020; these are cornerstones in implementation of ESD. To strengthen the feedback and updating of the EPs; more emphasis should be put on development and use of ESD monitoring tools. 
Towards Excellence: An Indexed, Refereed \& Peer Reviewed Journal of Higher Education / Ms.

\title{
Paramjit Kaur \& Prof. Saroj Sharma/ Page 102-112
}

\section{Bibliography:}

1. Creswell, John W. (2015). Educational Research: Planning, Conducting, and Evaluating Quantitative and Qualitative Research, $\left(4^{\text {th }}\right.$ ed $)$. India: Pearson Education

2. McKeown, R. (2002). The ESD Toolkit 2.0, United Nations Educational, Scientific and Cultural Organization.

3. National Education Policy (2020). Ministry of Education, New Delhi. Retrieved from https://www.education.gov.in/sites/upload_files/mhrd/files/NEP_Final_English_0.pdf

4. UNESCO. 2010. Education for Sustainable Development Lens: A Policy and Practice Review Tool: UNESCO, Paris.

5. United Nations Conference on Environment \& Development Rio de Janerio, Brazil. (1992). Agenda 21. Retrieved from http://www.un.org/esa/sustdev/agenda21.htm.

United Nations Decade of Education for Sustainable Development (2005 - 2014):

International Implementation Scheme. (2005). UNESCO: Paris. Retrieved from http://unesdoc. unesco.org/images/0014/001486/148650E.pdf

\author{
Ms. Paramjit Kaur \\ Research Scholar, University School of Education \\ Guru Gobind Singh Indraprastha University, New Delhi \\ Biology Teacher, The Srijan School, Model Town, Delhi \\ paramjit.gujral1@gmail.com \\ \& \\ Prof. Saroj Sharma \\ Chairperson, National Institute of Open Schooling (NIOS) \\ professorsarojsharma@gmail.com
}

